\title{
The Questionnaire Analysis Research on the Causes of College Students' Reticence in the English Classroom
}

\author{
Wang Xuehua \\ School of Foreign Languages \\ Southeast University (SEU) \\ Nanjing, China \\ Wangxuehua@nuaa.edu.cn
}

\author{
Chen Meihua \\ School of Foreign Languages \\ Southeast University (SEU) \\ Nanjing, China \\ meihuachen123@126.com
}

\begin{abstract}
The research efforts aiming at changing the phenomenon of Chinese students' reticence should be based on a full understanding of the various causes behind it. It has been revealed in this paper through questionnaire study that the seeming reticence is more likely to be the performance of learners' habitual classroom behavior resulting from the traditional learning environment, rather than the consequence of any inherent disposition of Chinese learners themselves. Accordingly, classroom reticence can be changed if the learning environment alters.
\end{abstract}

Keywords-Mainland students in China; reticence; learners' habitual behavior; questionnaire study

\section{INTRODUCTION}

Chinese students are alleged to be reticent in College English classroom in the recent ESL/EFL literature [1] [2][3][4][5][6]. Reticence in language class should be acceptable if active participation were not essential in language learning. However, the undoubted truth is the opportunities to produce language are important for acquisition. The importance lies in the fact that output pushes learners to process language more deeply [4]. And getting feedback from the teacher and their classmates enables learners to test hypotheses and refine their developing knowledge of the language system [7].

The long-term existence of reticence in English learning has brought unfavorable effects on Chinese learners' English proficiency. Therefore, there is a necessity to change students' reticent behavior in English class, and an overall analysis on the various causes of such reluctance is the premise to achieve this goal.

\section{LITERATURE REVIEW}

Some researchers have been carried out to explore the causes for students' reluctance to adopt active roles in the English class. Maintaining the Integrity of the Specifications

Amy Tsui and her informants [4] identified five principal factors accounting for the reluctance of students to speak up in class in secondary school classroom in Hong Kong. They were: a) students' perceived low proficiency in English; b) students' fear of mistakes and derision; c) teachers' intolerance of silence; d) uneven allocation of turns; e) incomprehensible input.Some possible causes of such alleged reticence in the research conducted by Liu, Ngar-fun and Littlewood, W. [6][9][10] at the University of Hong Kong were: a) lack of experience in speaking English; b) lack of confidence in spoken English, c) anxiety from high performance expectations, and d) perception of learner role. Again, in Hong Kong, an ethnographic study by Jane Jackson [3] investigated the reticence of Chinese students in four sections of an English medium undergraduate business course. Cheng Xiaotang [5] argued that if some Asian students were indeed observed to be quieter than expected in certain circumstances, the causes were situation specific rather than culturally preset.

The above findings have contributed a lot to the study on the reticent phenomenon, but Cheng's [5] conclusion lacks the empirical study, and the subjects of the researches carried out by Lin and Littlewood [6], Littlewood [10] and Jackson [3] on Chinese students are mainly restricted in Hong Kong district, while there are at least three aspects of differences in English learning environment between Hong Kong and Mainland areas: a) Roles of English in social life are different. According to Quirk's classification [11], Hong Kong lies in the outer circle of periphery varieties of English where English is widely used as a second language [4], while Mainland China is situated in the expanding circle of periphery varieties of English where English, as a foreign language, is learned in schools, but not used as a medium of instruction, nor as a language of communication [12]. b) Attitudes towards speaking English are different. c) Ways of testing in schools are different.

With the Mainland college students as the main subjects, the present research is to make an overall analysis of various causes behind the reticence with the aim to see whether the phenomenon of the students' reluctance in the college English classroom can be changed.

\section{EXPERIMENT DESIGN}

In order to be able to gain access to the opinions of a large and potentially diverse population, it was decided to use questionnaires, one for students and the other for teachers, as the main research instrument. And a Likert scale from 1 to 6 is used as " 1 ” for "Stongly agree” and “6” for "Stongly disagree”. 


\section{A. Subjects}

The questionnaire survey involved 512 non-English majors and 94 English teachers from six institutions of higher learning in Nanjing, Jiangsu Province of Mainland China.

\section{B. Questionnaires}

The rationale of both the student and teacher's questionnaires originated from Burns and Joyce's identification [4] of three sets of factors (cultural factors, linguistic factors and psychological/affective factors) that might cause the reticence in classroom activities involving speaking.

\section{PREsentation AND Discussion OF ResultDS}

\section{1) Main causes of reticence}

Among all the listed causes, Table I shows only those which score a mean of below 3.5

It is suggested, in the light of the similar order of the mean from teachers' response, that the students and the teachers share an agreement to some extent on the issue. Previous learning experience (cause 1), to which most importance has been attached here, reveals all that the students are supposed to do in the traditional class. These are presumably the characteristics of Chinese Confucian culture and tradition (cause 6). The finding is consistent with that of other researchers [13][8] who concluded that reticent and passive behavior results from certain cultural attitudes of Asian societies. However, respecting knowledge and knowledgeable persons does not mean that students should be compliant and passive to the teacher. Thus Confucian culture does not seem to be a convincing cause for Chinese students' reticence in class, that is to say, Chinese students are not born to adopt the passive classroom attitude.

Causes 2 and 3 as linguistic factors reveal the difficulty the teachers meet with to make the teaching tasks comprehensible and workable in consideration of students' current language competence of all levels. The other causes contributed to the reticence like anxiety, introvert personality and motivation (causes 4, 5 and 7) are similar to the discoveries of Tsui [4], Liu \& Littlewood [6] Jackson [3].

TABLE I

\begin{tabular}{|c|c|c|c|}
\hline \multicolumn{2}{|r|}{$\begin{array}{l}\text { Causes (arranged in a rising } \\
\text { order of the mean of students) }\end{array}$} & $\begin{array}{l}\text { Mean of } \\
\text { students }\end{array}$ & $\begin{array}{l}\text { Mean of } \\
\text { teachers }\end{array}$ \\
\hline 1 & Previous learning experience & 2.32 & 1.98 \\
\hline 2 & $\begin{array}{l}\text { Lack of required language } \\
\text { proficiency }\end{array}$ & 2.48 & 2.38 \\
\hline 3 & Uninteresting teaching content & 2.99 & 3.16 \\
\hline 4 & $\begin{array}{l}\text { Anxiety of making mistakes, } \\
\text { losing face }\end{array}$ & 3.05 & 2.27 \\
\hline 5 & Introvert personality & 3.17 & 2.74 \\
\hline 6 & $\begin{array}{l}\text { Result of Chinese Confucian } \\
\text { culture and tradition }\end{array}$ & 3.17 & 2.76 \\
\hline 7 & $\begin{array}{l}\text { Lack of motivation of learning } \\
\text { English well }\end{array}$ & 3.29 & 3.26 \\
\hline
\end{tabular}

2) Learner's habitual classroom behavior
It is not beyond expectation that almost all the means in this part are above 3.5 (see Table II) as reticence and passivity is regarded to be of wide existence: students do not ask questions (item 2); not share their ideas (item 3); not question others (items 4 and 5). However, the mean of 2.98 and 2.76 from both students and teachers about the statement "participate in classroom activities actively" (item 1) shows that both the learners and teachers regard learners' classroom behavior as active one though there is a wide allegation of reticence. Thus the results bring us a very worthwhile reconsideration of what is "active classroom participation" in Mainland learners and teachers' eyes. From the data, we can infer that in the Mainland context, learners might participate in classroom activities "actively" by paying attention "quietly" to what is going on in the classroom and concentrating on what they need to learn.

TABLE II

\begin{tabular}{|c|c|c|c|}
\hline \multicolumn{2}{|c|}{ Classroom Behavior } & $\begin{array}{c}\text { Mean of } \\
\text { students }\end{array}$ & $\begin{array}{c}\text { Mean of } \\
\text { teachers }\end{array}$ \\
\hline 1 & Participate in classroom activities \\
actively. & 2.98 & 2.76 \\
\hline 2 & $\begin{array}{c}\text { I raise questions the minute I } \\
\text { encounter them. }\end{array}$ & 3.91 & 3.90 \\
\hline 3 & I am eager to share my ideas. & 3.66 & 3.63 \\
\hline 4 & $\begin{array}{c}\text { I will question him/her if I hold a } \\
\text { different view from the teacher's. }\end{array}$ & 3.96 & 3.60 \\
\hline 5 & $\begin{array}{c}\text { I will question them if I hold a } \\
\text { different view from my classmates'. }\end{array}$ & 3.14 & 3.68 \\
\hline \multicolumn{2}{|c|}{ College students' behavior in College English class on a scale of 1 [strongly agree] to 6 [strongly } \\
disagree]
\end{tabular}

3) Influence of the Grammar-Translation Method

The data from Table III reveal the influence of the longdominated Grammar-Translation Method (see Table III). The scored mean of below 3.5 indicates both students and teachers hold a tolerant attitude to the principal characteristics of the Grammar-Translation Method, where accuracy of grammar, vocabulary and pronunciation is emphasized (item 1); drill exercises are very important as the sentence is the basic unit of teaching and language practice (item 2); reading and writing are the major focus; little or no systematic attention is paid to speaking or listening (item 3). Thus, English language learning means a tedious experience of memorizing endless lists of unusable grammar rules and vocabulary and attempting to produce perfect translations of stilted or literary prose [14], which, to a great extent, contributes to the reticence and reluctance of learners.

TABLE III

\begin{tabular}{|c|c|c|}
\hline $\begin{array}{c}\text { Influence of the traditional } \\
\text { Grammar-Translation Method }\end{array}$ & $\begin{array}{c}\text { Mean of } \\
\text { students }\end{array}$ & $\begin{array}{c}\text { Mean of } \\
\text { teachers }\end{array}$ \\
\hline $\begin{array}{c}\text { Learning focuses on the importance of } \\
\text { correct grammar, vocabulary and } \\
\text { pronunciation. }\end{array}$ & 2.66 & 3.18 \\
\hline $\begin{array}{c}\text { Materials contain a lot of drill exercises, } \\
\text { e.g. structure-based dialogues. }\end{array}$ & 2.78 & 3.23 \\
\hline $\begin{array}{c}\text { A lot of attention is paid to improve } \\
\text { written communicative competence. }\end{array}$ & 3.07 & 3.03 \\
\hline \multicolumn{2}{|c|}{ Influence of the long-dominated Grammar-Translation Method on a scale of 1 [strongly agree] to 6 } \\
[strongly disagree]
\end{tabular}

Moreover, under such a learning environment, the teacher's role and authority have been exaggerated. And the result is learners' over-dependence on the teacher (see Table IV). 
Learners regard the teacher as a "walking dictionary" and the teacher should help them solve all the language problems they encounter (item 1). And learners are only expected to receive knowledge without contributing to the learning process, let alone question a knowledgeable teacher (item 2).

TABLE IV

\begin{tabular}{|c|c|c|c|}
\hline \multicolumn{2}{|c|}{$\begin{array}{c}\text { Learners' over-dependence on the } \\
\text { teacher }\end{array}$} & $\begin{array}{c}\text { Mean of } \\
\text { students }\end{array}$ & $\begin{array}{c}\text { Mean of } \\
\text { teachers }\end{array}$ \\
\hline 1 & $\begin{array}{c}\text { The teacher helps students to find } \\
\text { out for themselves the language } \\
\text { they need to get things done. }\end{array}$ & 1.96 & 2.54 \\
\hline 2 & $\begin{array}{c}\text { I will question him/her if I hold a } \\
\text { different view from the teacher. }\end{array}$ & 3.96 & 3.60 \\
\hline \multicolumn{2}{|c|}{ Learners' over-dependence on the teacher on a scale of 1 [strongly agree] to 6 [strongly disagree] }
\end{tabular}

The traditional Grammar-Translation Method affects not only the in-class learning habits but also the after-class learning experience (see Table V).

TABLE V

\begin{tabular}{|c|l|c|c|}
\hline \multicolumn{2}{|c|}{$\begin{array}{c}\text { Frequency of participating in these } \\
\text { after-class activities }\end{array}$} & $\begin{array}{c}\text { Mean of } \\
\text { students }\end{array}$ & $\begin{array}{c}\text { Mean of } \\
\text { teachers }\end{array}$ \\
\hline 1 & Keep a vocabulary notebook & 2.29 & 1.50 \\
\hline 2 & Listen to the radio/tapes & 2.47 & 1.81 \\
\hline 3 & Read newspapers/books & 2.48 & 2.18 \\
\hline 4 & Watch TV programs & 2.72 & 2.09 \\
\hline 5 & $\begin{array}{l}\text { Communicate with friends, } \\
\text { classmates, foreigners, etc. }\end{array}$ & 3.02 & 2.40 \\
\hline 6 & Write to friends & 3.46 & 2.28 \\
\hline 7 & Take lessons outside school & 3.61 & 2.12 \\
\hline \multicolumn{2}{|c|}{ Frequency of participating in these out-of-class activities on a scale of 1 [often ] to 4 [never] }
\end{tabular}

In this part, both the students and teachers are asked to rate the frequency of their /or their students' participation of the after-class English activities. Those activities which scored below 2.5 means students often or sometimes take part in them. Keeping a vocabulary notebook (item 1) and reading newspaper or books (item 3) are those activities that are the typical reflection of the Grammar-Translation Method. Writing to friends (item 6 ) that used to be very popular among college students has already been replaced by e-mails and short messages. Watching TV programs (item 4) should be very attractive to students, but the frequency indicated by the data is not very high due to the limited dormitory facilities and conditions. As neither speaking nor listening is the major focus of the Grammar-Translation Method, little attention is paid to communicating with others (item 5), but more attention is paid to practicing listening ability (item 2) as listening comprehension is a compulsory testing item in all sorts of English tests. Taking lessons outside school (item 7) is not very widespread among learners, possibly because those freshmen and sophomores have not set a goal of either going abroad or entering graduate school after graduation. In addition, a strange phenomenon is that for each item the mean from the teachers is lower than that from the students, which means the expectation from teachers about students' participation in after-class English activity is much higher than what learners actually do after class.
4) Learners' desire of adopting a more active role in classroom activities

The data from Table VI indicate that students in Mainland China are quiet, passive participators, which is likely to be a result of the traditional educational environment. However, similar to the findings of Jackson [3], Cheng [5], Littlewood [9] and Liu and Littlewood [6], the data from the questionnaires also suggest that learners do not want to remain in their shells. Instead, they hunger to be involved in "overt talk", namely, they are ready to adopt a more active role. Table VI reflects such eagerness from different aspects.

TABLE VI

\begin{tabular}{|c|c|c|c|}
\hline \multicolumn{2}{|r|}{$\begin{array}{l}\text { Learners' desire of adopting a more } \\
\text { active role in classroom activities }\end{array}$} & \multirow{2}{*}{$\begin{array}{c}\begin{array}{c}\text { Mean of } \\
\text { students }\end{array} \\
1.81\end{array}$} & \multirow{2}{*}{$\begin{array}{c}\begin{array}{c}\text { Mean of } \\
\text { teachers }\end{array} \\
2.32\end{array}$} \\
\hline 1 & $\begin{array}{l}\text { A lot of attention is paid to } \\
\text { improving oral communicative } \\
\text { competence. }\end{array}$ & & \\
\hline 2 & $\begin{array}{l}\text { More communicative activities, e.g. } \\
\text { role play and discussion, are } \\
\text { contained in classroom teaching. }\end{array}$ & 2.32 & 2.01 \\
\hline 3 & $\begin{array}{l}\text { Learner-centered instruction and } \\
\text { learners’ participation are } \\
\text { encouraged. }\end{array}$ & 1.99 & 1.64 \\
\hline 4 & $\begin{array}{l}\text { Group work (group of } 3 \text { or } 5 \text { ) is } \\
\text { advocated. }\end{array}$ & 2.40 & 2.05 \\
\hline 5 & $\begin{array}{c}\text { The teacher explains the learning } \\
\text { purpose of class activities. }\end{array}$ & 2.62 & 2.34 \\
\hline 6 & $\begin{array}{l}\text { The relaxed classroom atmosphere is } \\
\text { important for English speaking } \\
\text { practice. }\end{array}$ & 1.52 & 1.66 \\
\hline 7 & $\begin{array}{l}\text { Knowledge is something that the } \\
\text { teacher should pass on to learners } \\
\text { rather than something learners should } \\
\text { discover themselves. }\end{array}$ & 4.82 & 4.90 \\
\hline 8 & $\begin{array}{l}\text { Teachers are expected (rather than } \\
\text { learners themselves) to be } \\
\text { responsible for evaluating how much } \\
\text { learners have learned. }\end{array}$ & 3.90 & 3.48 \\
\hline
\end{tabular}

Both the learners and the teachers' responses clearly indicate that the stereotype of Chinese students as "quiet, passive learners" does not reflect the role they would like to adopt in class. They do not want to receive knowledge passively (item 7 , mean $>3.5$ ); they do not expect to be evaluated only by teachers (item 8 , mean $>3.5$ ); they see the importance of knowing the learning purpose of the classroom activities (item 5, mean<2.5); and they express their strongly positive attitude to communicative activities that they are actively engaged in (items 1,2 and 3 , mean $<2.5$ ). The preferences are consistent with the characteristic which Littlewood [10] found in Hong Kong students that learners may feel more relaxed when they work in small groups than when the whole class works together (c.f. items 4 and 6, mean<2.5).

Learners' strong desire of participating actively in classroom activities is also stirred by their high motivation of learning English well with all the means of below 3.5 (see Table VII). In particular, the data show that students have strong instrumental motivation driven by career pursuing (item 1) and national English test (item 2), and not weak integrative 
motivation of appreciating the sound of the English language (item 3), which is consistent with the findings of Fang [15].

TABLE VII

\begin{tabular}{|c|c|c|c|}
\hline \multicolumn{2}{|r|}{$\begin{array}{c}\text { Learners' motivation of learning } \\
\text { English well }\end{array}$} & $\begin{array}{l}\text { Mean of } \\
\text { students }\end{array}$ & $\begin{array}{l}\text { Mean of } \\
\text { teachers }\end{array}$ \\
\hline 1 & $\begin{array}{l}\text { I learn English in order to improve } \\
\text { my career prospects. }\end{array}$ & 2.04 & 2.66 \\
\hline 2 & A lot of attention is paid to CET-4. & 2.44 & 3.50 \\
\hline 3 & $\begin{array}{l}\text { I like the sound of the English } \\
\text { language. }\end{array}$ & 2.78 & 3.81 \\
\hline 4 & $\begin{array}{l}\text { Learning English enables me to see } \\
\text { and understand the world in a } \\
\text { different way. }\end{array}$ & 2.91 & 2.40 \\
\hline 5 & $\begin{array}{l}\text { English is the sign of an educated } \\
\text { person in China }\end{array}$ & 3.05 & 2.97 \\
\hline 6 & $\begin{array}{l}\text { The use of English is one of the } \\
\text { most important factors that have } \\
\text { contributed to China's } \\
\text { development. }\end{array}$ & 3.26 & 3.11 \\
\hline
\end{tabular}

\section{CONCLUSION}

From the above data presentation and discussion, we can get the following conclusions:

Learners' previous learning experience, apart from other linguistic and affective factors, is regarded as the most important cause of learners' reticence in English class. Such learning experience has been formed not in the Confucian Culture in Mainland China, but in the traditional learning environment where the Grammar-Translation Method plays a major role. In other words, Mainland students' reticence is more likely to be the performance of their habitual classroom behaviors that have been formed in the traditional learning circumstances than to be the consequence of any inherent dispositions of the students themselves. This is consistent with Littlewood's finding [10] from the empirical study on Hong Kong students and Cheng's conclusion [5]from literature study on Asian students. So reticence can be changed if the learning environment alters.

Mainland students and teachers have their own concept of "active participation" which includes not only overt talk but also quiet attentiveness. So it is equally important to improve the degree and the conception of classroom participation for the sake of alleviating reticence in English class.

Though quiet attentiveness is considered as "active participation”, students express positive attitudes towards overtly active participation in classroom activities and high motivation to learn English well despite some linguistic difficulties for them. That is, students would like to play a more active role, if the learning environment allows or encourages it.

The further research might conduct a new teaching approach to change the reticence in College English classroom based on the above questionnaire data analysis and the correspondent conclusions.

\section{ACKNOWLEDGEMENTS}

The paper is supported by the Special fund entitled "A Study on the Transition of College English Teaching Oriented towards EAP” for basic scientific research in Humanities and Social Sciences of SEU, 2012, under contract number SKCX20120025)

\section{REFERENCES}

[1] Chen, T. 2003. Reticence in class and on-line: two ESL students' experiences with communicative language teaching. System,31: 259-281.

[2] Rao, Z. 2002. Chinese students' perceptions of communicative and noncommunicative activities in EFL classroom. System, 30:85-105.

[3] Jackson, J. 2002. Reticence in second language case discussions: anxiety and aspirations. System, 30:65-84.

[4] Nunan, D. 2001. Second language teaching and learning. Beijing: Foreign Language Teaching and Research Press.

[5] Cheng, X. 2000. Asian students' reticence revisited. System, 28: 435446.

[6] Liu, N., \& W. Littlewood. 1997. Why do many students appear reluctant to participate in classroom learning discourse. System, 25/3: 371-384.

[7] Hedge, T. 2002. Teaching and learning in the language classroom. Shanghai: Shanghai Foreign Language Education Press.

[8] Ferris, D., \& T. Tagg. 1996. Academic listening/speaking tasks for ESL students: problems, systems, and implications. TESOL Quarterly, 30/2:297-320

[9] Littlewood, W. 2000. Do Asian students really want to listen and obey? ELT Journal 54/1: 31-36.

[10] Littlewood, W. 2004. Students' perspectives on interactive learning. In J. Jones, O. Kwo \& T. Moore (eds.) Developing learning environment in higher education. Hong Kong: Hong Kong University Press.

[11] Zhang, Y., \& Q. Zhang. 2004. Globalization of English and teaching EFL in China. CELEA Journal, 27/5: 22-26.

[12] Hu, Z., R. Liu, , \& Y. Li. (eds.) 1998. Linguistics: A course book. Beijing: Beijing University Press.

[13] Flowerdew, J., \& L. Miller. 1995. On the notion of culture in L2 lectures TESOL Quarterly, 29/2:345-373.

[14] Richards, J.C., \& T. S. Rodgers. 1996. Approach and methods in language teaching. Cambridge: Cambridge University Press.

[15] Fang, F. (2006). My experience of learning languages and teaching English in China - A narrative inquiry. English Teaching: Practice and Critique. 5/2: 117-129 http://education.waikato.ac.nz/research/files/etpc/2006v5n2nar2.pdf 